\title{
Measuring Financial Performance in Infrastructure: An Application to Europe and Central Asia
}

\author{
Jane O. Ebinger
}

\begin{abstract}
Unintentional implicit subsidies (hidden costs) to public utilities can be considered an illegitimate claim on public resources. This paper examines the role and sources of hidden costs in the energy and water sectors in the Europe and Central Asia region (ECA). It reviews available data and introduces a modelthe Hidden Costs Calculator that can be used to quantify the burden on governments of infrastructure policy and implementation decisions. This simple-to-apply model provides insight into three key components of hidden costs that affect infrastructure-poor bill collection rates, excessive losses due to inefficient operations or theft from the networks, and tariffs set below cost-recovery rates. The major advantage of this model is that, using existing data, it can provide a single measure for hidden costs that can be easily calculated, tracked, and reported; therefore it can monitor and benchmark trends across sectors and countries without extensive or costly data collection. The model compares the difference between actual revenues and revenues that could be anticipated in a well-functioning system operating with cost-covering tariffs, bills paid, and losses normative for networks of a certain age and design. The underlying premise is that quantifying the order of magnitude of each component of hidden costs has potential for strengthening infrastructure policy dialogue and influencing decision makers who allocate scarce budgetary resources.
\end{abstract}

Keywords: Infrastructure, utilities, finance, hidden costs, subsidies

World Bank Policy Research Working Paper 3992, August 2006

The Policy Research Working Paper Series disseminates the findings of work in progress to encourage the exchange of ideas about development issues. An objective of the series is to get the findings out quickly, even if the presentations are less than fully polished. The papers carry the names of the authors and should be cited accordingly. The findings, interpretations, and conclusions expressed in this paper are entirely those of the authors. They do not necessarily represent the view of the World Bank, its Executive Directors, or the countries they represent. Policy Research Working Papers are available online at http://econ.worldbank.org.

\section{Infrastructure Department \\ Europe and Central Asia Region (ECA) \\ The World Bank}




\section{Abbreviations and Acronyms}

\begin{tabular}{ll}
$\%$ & Percent \\
ACRP & Average cost recovery price \\
Bank & The World Bank \\
CEE & Central and Eastern Europe \\
CIS & Commonwealth of Independent States \\
Cu.m & Cubic Meter \\
EAP & East Asia Pacific Region \\
ECA & Europe and Central Asia \\
ECSIE & Infrastructure Unit, ECA Region, The World Bank \\
EU & European Union \\
FSU & Former Soviet Union \\
FSU-LI & FSU low income countries \\
FSU-MI & FSU middle income countries \\
FY & Financial Year \\
GDP & Gross Domestic Product \\
ISPA & Instrument for Structural Policies for Pre-Accession \\
Km & Kilometers \\
KWh & Kilo watt hours \\
LI & Low Income \\
Mcm & Thousand cubic meters \\
MWh & Mega watt hours \\
OECD & Organization for Economic Cooperation and Development \\
US\$ & United States dollars \\
USc & United States cents \\
USSR & Union of Soviet Socialist Republics \\
Veh. & Vehicle \\
WAET & Weighted Average End User Tariff \\
& \\
\hline
\end{tabular}




\section{Table of Contents}

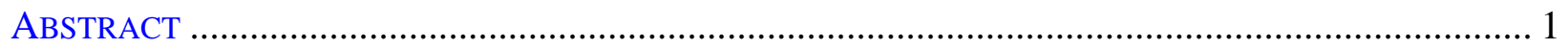

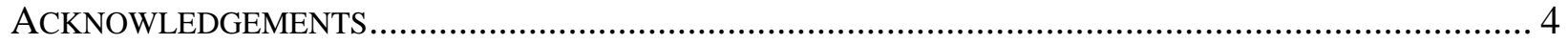

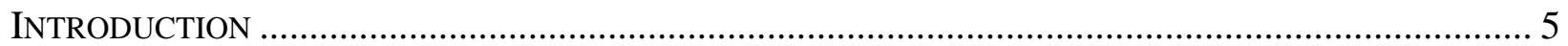

The Cost OF PoLicy CHOICES ...................................................................................... 5

The Hidden Costs Calculator Model............................................................................ 5

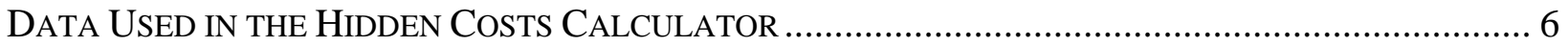

KEY Findings: HidDEN CostS In THE ECA REGION ARE SignifiCANT...................................... 6

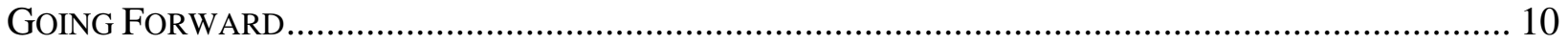

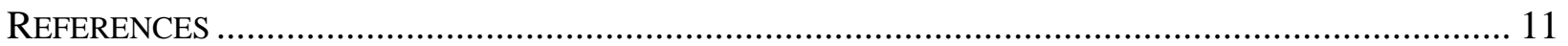

Annex 1. Calculating Hidden Costs in the Energy And Water Sectors......................... 12

Annex 2. Data Sources, Availability, And Definitions ............................................... 21 


\section{Acknowledgements}

This working paper is based on the report "Measuring Financial Performance in Infrastructure" (World Bank, 2006). The report draws upon information from a variety of sources including publicly available information and information available to the World Bank as a result of studies commissioned by the Bank, undertaken by Bank staff or otherwise provided to the Bank. The World Bank has used the most up to date data that was available to it in preparing this report.

The report was prepared by a team from the Infrastructure and Energy Unit of the Europe and Central Asia Region of the World Bank under the guidance and supervision of Lee Travers (Sector Manager ECSIE). Task team members comprised: Jane Ebinger, Alexander Danilenko, Maka Lomaia, Subramaniam Janakiram, Soumya Chattopadhyay, Sanjay Sinha, Cem Alkan, Alfiya Mirzagalyamova, Josephine Kida and Larisa Marquez.

The report benefited from review, comments and input from: Paul Amos, Michel Audige, Alex Bakalian, Ani Balabanyan, Cecilia Briceno-Garmendia, Bojan Borojevic, Jean-Charles Crochet, Mark Davis, Istvan Dobozi, Anca Dumitrescu, Ben Eijbergen, Lev Freinkman, Katherina Gassner, Sandu Ghidirim, Ellen Hamilton, Richard Hamilton, Marat Iskakov, Serdar Japbarov, Peter Johansen, Peter Kelly, David Kennedy, Henri Kerali, Iftikhar Khalil, Anupam Khanna, Sunja Kim, Elena Klochan, Martha Lawrence, Astrid Manroth, Farid Mamedov, Joseph Melitauri, Yuri Miroshnichenko, Celestin Monga, James Moose, Ana Otilia Nutu, Eric Petersen, Silvia Poghinu, Taras Pushak, Cesar Quieroz, Lulin Radulov, Marianne Fay, Peter Roberts, Gevorg Sargsyan, Raghuveer Sharma, George Tharakan, Peter Thomson, Cordula Thum, Gleb Zinoviev, and many others who spent time making the review possible. 


\section{Introduction}

Reliable and affordable infrastructure is essential for a well-functioning economy. Today in Europe and Central Asia (ECA) underperforming public utilities impede more rapid economic growth. This working paper raises a constellation of issues-high losses, non-payment of bills, and tariffs set below costrecovery rates - that block progress in the power, natural gas, and water sectors. The paper reviews available data on these sectors and begins to develop a model to quantify the burden on national budgets of infrastructure policy and implementation decisions. The intention is to widen opportunities for overall improvements in allocating scarce budgetary resources by offering policymakers data that will be useful to (a) understand the order of magnitude of current hidden fiscal costs, (b) estimate the costs of current and future policy choices, (c) and reduce the burden on consumers.

Implicit subsidies to public utilities can be considered an illegitimate claim on public resources. Direct subsidies to utilities are formally allocated and formally recorded 'on the books.' For a discussion of implicit subsidies and their impact on the quasi fiscal deficit, see Saavalainen and Ten Berge (2004). In contrast, 'hidden' costs, although accumulated by utilities, go unrecorded, thereby creating a fiscal burden on the local or national government that amounts to a hidden subsidy. Typically utilities compensate for these hidden costs by reducing investment in maintaining the utility; they may also delay or forego essential maintenance and repairs or reduce the workforce, actions that trigger a downward spiral of significant deterioration in the value of assets, declining service quality, and increasing cost for each unit of service provided. When this happens, losses are increased substantially and abnormally high investment is required to carry out repairs, which is rarely cost effective.

\section{The Cost of Policy Choices}

The vicious cycle - that begins with hidden costs and proceeds to hidden subsidies - means that when governments finally absorb accumulated debts, they do so at the cost of adding to the national debt or reducing funding for other programs. This cycle has persisted in part because of difficulties in quantifying the order of magnitude of 'hidden costs.' The Hidden Costs Calculator model — developed through collaboration between the World Bank Group and the International Monetary Fund (Saavalainen and Ten Berge, 2006) — was designed to provide a single measure for all implicit subsidies so that policymakers can weigh the price of policy actions (or inactions) that could, but do not, have a fiscal offset. One important criterion for developing the model was to calibrate carefully the tradeoffs between complexity and comprehensiveness on the one hand and ease of use on the other. The major advantage of this model is that - using existing data - it can provide a single measure for hidden costs that can be easily calculated, tracked, and reported; therefore it can monitor and benchmark trends across sectors and countries without extensive or costly data collection.

\section{The Hidden Costs Calculator Model}

The model, the Hidden Costs Calculator, is designed to provide insight into three key components of hidden costs affecting ECA infrastructure: poor bill collection rates; excessive losses due to inefficient operations or theft from the network in power, gas or water systems; and tariffs set below cost-recovery rates (i.e., amounts needed for long-run operations and maintenance, investment, and normative losses). This model compares the difference between actual revenues and revenues that could be anticipated in a well-functioning system operating with cost-covering tariffs, bills paid, and losses normative for networks of a certain age and design. 
In its final form the applied model to estimate hidden costs, $\mathrm{H}$ is expressed as:

$\mathrm{H}=\mathrm{R}^{*}-\mathrm{R}$

where $\mathrm{R}^{*}$ is the expected revenue and $\mathrm{R}$ is the actual revenue. $\mathrm{H}$ can be expressed alternatively as a function of tariffs below cost recovery, unaccounted losses and poor collections, by substituting for these variables:

$\mathrm{H}=\mathrm{Qe}(\mathrm{Tc}-\mathrm{Te})+\mathrm{Qe}$ Tc $(\mathrm{lm}-\mathrm{ln}) /(1-\operatorname{lm})+\mathrm{Qe}$ Te $(1-\mathrm{Rct})$

where,

$\mathrm{Qe}=$ end user consumption

$\mathrm{Tc}=$ average cost-recovery price

$\mathrm{Te}=$ weighted average end user tariff

$\operatorname{lm}=$ total loss rate

$\ln =$ normative loss rate

Rct $=$ collection rate

See Annex 1 for a full derivation.

Note that tariffs set below cost-recovery levels as a recognized policy should be considered an explicit subsidy and therefore should be deducted from the overall calculation. In this case the correct measure of hidden costs would be as follows:

$\mathrm{H}=\mathrm{R}^{*}-\mathrm{R}-\mathrm{T}$

where $\mathrm{T}$ is the amount of capital or other transfer. No attempt has been made to estimate $\mathrm{T}$ in this paper and hidden costs may in some cases be overestimated.

\section{Data Used in the Hidden Costs Calculator}

Hidden costs estimates in the energy sector span 22 ECA countries. However due to decentralization of water service provision, coverage in this paper is limited to the 16 countries with available data. Data collection has focused on 2000 to 2003 using internationally known sources or existing data collection instruments where possible. Since there are no external datasets of desired financial performance (e.g., average cost-recovery price), supplemental data have been applied (from existing World Bank Group publications and reports; from World Bank Group and International Monetary Fund sector specialists). The paper presents information reported in external datasets or by utilities that have been checked for inconsistencies and outliers but no special audit has been conducted. Specific assumptions that may be used in place of sector specific data, including normative loss rates and average cost recovery prices, are presented in Annex 1. All data presented in this paper are in 2001 constant US dollars to eliminate trends or fluctuations that result from currency conversions.

\section{Key Findings: Hidden Costs in the ECA Region are Significant}

Throughout the region during this period, the power sector's share of hidden costs has been the largest. The water sector and gas sector contributions are of similar magnitude to each other but their combined impact is still less that that of the power sector. Tariffs set below the cost-recovery rates is the single most significant factor in the energy sector-power and gas while unaccounted losses are the main factor in the water sector. 
Hidden costs in the power sector averaged 4.4 percent of gross domestic product (GDP) in 2003, down from double that figure in 2000. About half of this decline is due to an increase in GDP, but the remainder is attributed to improved sector performance. Since 2000, hidden costs in the gas and water sectors have changed little-2002 estimates were 1.0 percent of GDP for gas and 1.2 percent for water. Such minor movement in region-wide hidden cost estimates for the gas and water sectors makes trend analysis difficult. However, applying the model to national datasets frequently makes it possible to discern country-wide trends.

\section{Power Sector}

Throughout the region, tariffs set below cost-recovery rates accounted for 67 percent of aggregate hidden costs in 2003, followed by unaccounted losses at 22 percent, and poor collections at 11 percent. Overall, the aggregate value of total hidden costs declined by about 48 percent from a value of US\$ 30.1 billion in 2000 to US\$ 15.9 billion in 2003. ${ }^{1}$ The largest declines were in Russia (70 percent, from US\$ 14.2 billion in 2000 to US\$ 4.2 billion in 2003) and Bosnia (62 percent, from US\$ 251.5 million to US\$ 96 million). Notably, two countries with high hidden costs that differ from other countries by a wide margin are Tajikistan at 16 percent of GDP and Uzbekistan at 12 percent.

- Tariffs and cost-recovery rates. In absolute terms the contribution to overall hidden costs due to tariffs set below cost recovery totaled US $\$ 10.6$ billion in 2003. In relative terms, these costs have declined from 5.4 percent of GDP in 2000 to 2.6 percent GDP in 2003, despite increasing consumption across the region. Two factors contributed to this decline-GDP increased and the gap narrowed between the average cost-recovery price and the weighted average end user tariff. In Turkey tariffs exceeded cost-recovery levels in 2003, and in Moldova, 2002, eliminating this form of hidden cost. Over the same period in Croatia cost-recovery levels and weighted-average tariffs converged significantly. In 2003 high hidden costs persisted, due to tariffs set below costrecovery levels, in Tajikistan-14 percent of GDP, and Moldova—8.0 percent.

- Unaccounted Losses. Region-wide, hidden costs due to unaccounted losses initially increased from 2.0 percent of GDP in 2000 to 2.2 percent in 2001, but then steadily declined to 1.1 percent in 2003. ${ }^{2}$ During 2003, hidden costs due to unaccounted losses were highest in Former Soviet Union (FSU)-Low Income (LI) countries-Kyrgyz Republic (4.5 percent of GDP), Georgia (3.3 percent), Moldova (3.2 percent) and Armenia (2.2 percent). Total losses in these countries were in excess of 26 percent of domestic supply. In all other countries unaccounted losses comprised less than 2.0 percent of GDP where total losses ranged between 10 and 20 percent of domestic supply. The largest decline in unaccounted losses (as a proportion of GDP) occurred in Belarus and Bosnia — each more than 100 percent. There was a corresponding decline in total losses in Bosnia.

\footnotetext{
${ }^{1}$ Excluding Hungary and Turkmenistan for which no data were available.

${ }^{2}$ Excluding Hungary and Turkmenistan-no data available.
} 


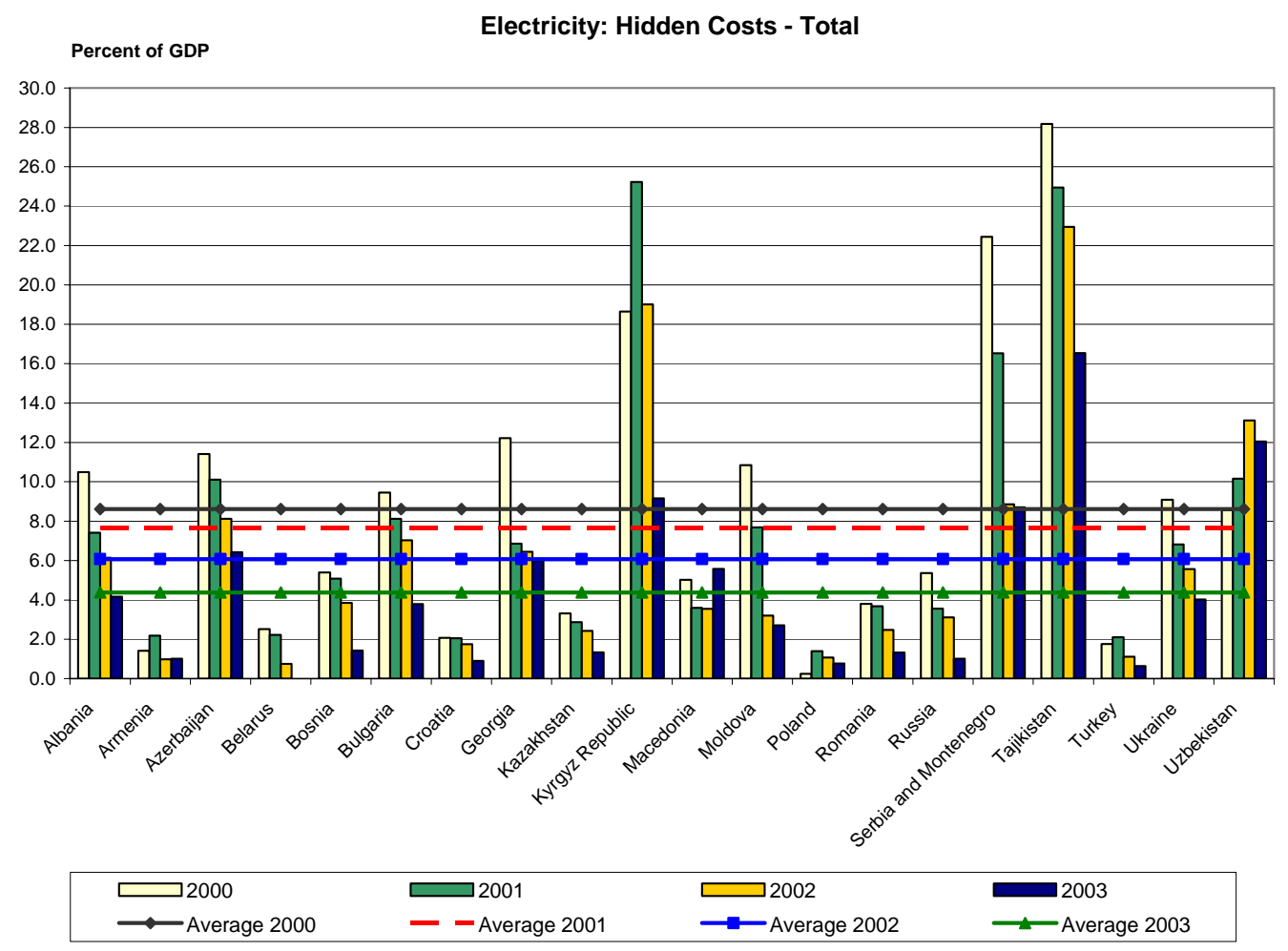

\section{Natural Gas Sector}

Across the Region tariffs set below cost-recovery levels accounted for 70 percent of total hidden costs, collection failures at 29 percent, and unaccounted losses at 1.0 percent. Hidden costs for natural gas remained below 2.0 percent of GDP for all years and in all countries except Ukraine (in earlier years) and Uzbekistan, where they were between 3.0 and 6.0 percent. Overall in the Region hidden costs declined from US\$ 6.6 billion in 2000 to US\$ 4.7 billion in 2002. In absolute values, Ukraine had the largest decrease in the three years prior to 2002 (a drop of US\$ 749 million); in relative terms Poland had the largest decline-64 percent in the same three years.

- Natural gas tariffs and cost recovery. Region-wide, in relative terms, hidden costs due to tariffs set below cost recovery declined from 0.8 percent to 0.6 percent of GDP, despite a 13 percent increase in end-user consumption for the period ending in 2002. This shows a convergence between average cost-recovery prices and weighted average end-user tariffs. In constant 2001 US\$, hidden costs from tariffs set below cost-recovery levels declined 35 percent—from US\$ 5.1 billion in 2000 to US\$ 3.3 billion in 2002. The largest decline in hidden costs occurred in Central and Eastern European (CEE) countries. Azerbaijan, Belarus, Kyrgyz Republic, and Uzbekistan increased over this period.

- Natural gas - collection rates. During 2000-02, hidden costs due to collection failures remained largely unchanged at around 0.4 percent of GDP, roughly US\$ 90 million. This is consistent with relatively small changes in collection efficiency. Other than Tajikistan, ${ }^{3}$ ECA countries improved their collection rates very gradually, reflecting diminishing scope for potential revenue leakages due to poor revenue collection institutions. Marked differences existed in collection rates across the Region; Georgia's rate remained low at 25 percent; Croatia, Moldova, Poland, and Turkey

\footnotetext{
${ }^{3}$ Tajikistan's collection rates for the first three years were in the 50-55 percent range, and spiked to 100 percent in 2003.
} 
remained between 78 and 90 percent. No country for which data were available exhibited a decline in collection rates.

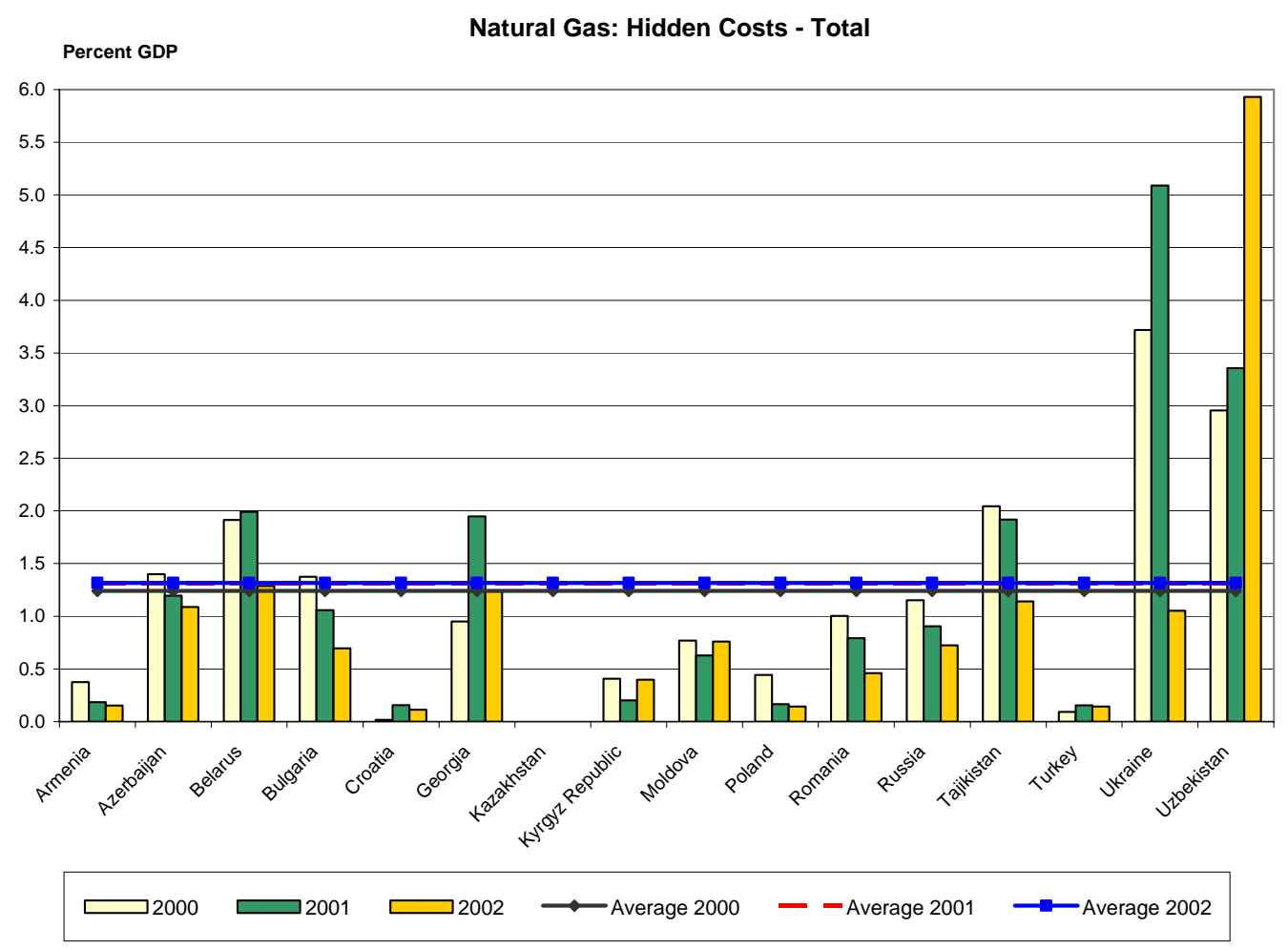

\section{Water Sector}

During 2002, hidden costs (in absolute terms) comprised-unaccounted losses, 50 percent; tariffs set below cost, 43 percent; poor collections, 7.0 percent. Hidden costs in all countries and for all years are below 2.5 percent of GDP, except Armenia and Moldova. In relative terms, hidden costs in the region overall, as a proportion of GDP, increased from 0.9 percent in 2000 to 1.2 percent in 2002 . However, the aggregate value of hidden costs in this sector declined between 2000-02 by about 30 percent, from US\$ 2.5 billion in 2000 to US\$ 1.8 billion in 2002. The largest declines in hidden costs were for Russia and Tajikistan—a decline of around 70 percent in each country in the same period.

- Water-unaccounted losses. Former Soviet Union countries contributed most to an increasing trend of hidden costs due to unaccounted losses, which rose from an average of 0.6 percent of GDP in 2000 to 0.9 percent in 2002; from US\$ 626 million to US\$ 939 million. This is consistent with deteriorating integrity of supply networks evidenced by a rise in total system losses (water abstracted minus water billed) from 32 percent in 2000 to 39 percent in 2002. Losses increased the most in FSU-Low Income countries, perhaps indicating deteriorating supply networks. ${ }^{4}$

- Water-tariffs and cost recovery. Overall hidden costs due to tariffs set below cost-recovery levels decreased 31 percent from US\$ 1.140 million to US\$ 785 million, led by FSU-Middle Income countries (55 percent over the period). However, data for 2003, while not covering all countries, showed an overall increasing trend. As a percentage of GDP this has remained on average between 0.4-0.5 percent.

\footnotetext{
${ }^{4}$ Although in absolute terms losses in Azerbaijan were the lowest across all countries.
} 


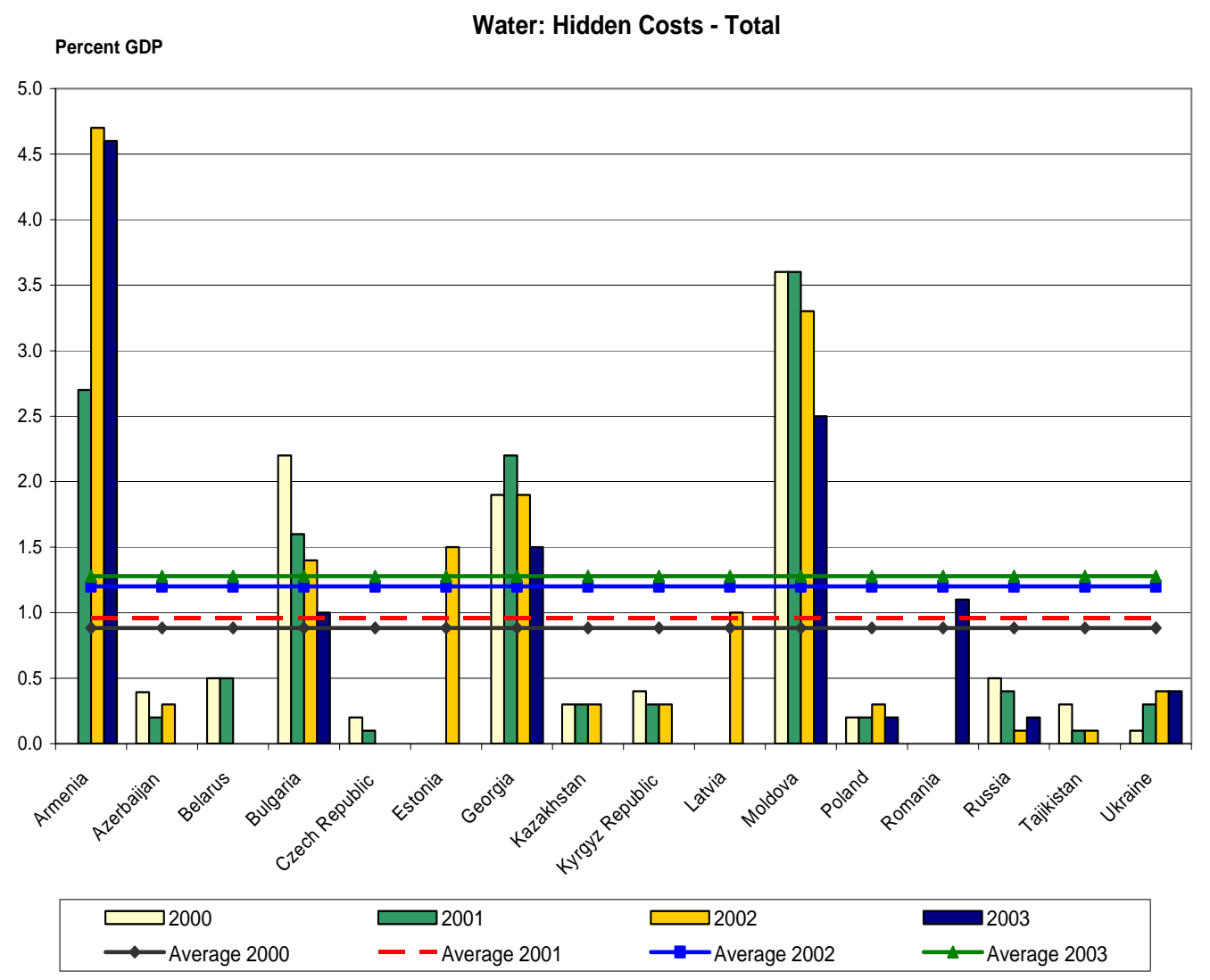

\section{Going Forward}

This exercise demonstrated that estimating the order of magnitude of hidden costs is worth pursuing. In the energy and water sector, the intention is to continue to update this dataset as information becomes available through external sources for additional countries for 2004 and onward. Future updates will be available through the website http://ecadata-worldbank.org. 


\section{References}

Albania (2003), National Water Association Report

Belarus Ministry of Environment (2004), Environment Status Report (in Russian)

ENERDATA, http://www.enerdata.fr

ERRANET, http://www.erranet.org/Products/Tariff/Database/TariffIndex

IBNET, http://ib-net.org

ISPA (1995 - 2005), Press releases on water and sanitation grants

ISPA (2000 - 2004), Increasing Involvement of the Local Authorities of the Baltic States in the EU Enlargement Process

ISPA (2001), National ISPA Strategy for Slovenia Environmental Sector

OECD www.oecd.org/document/49/0,2340,en_2649_34343_1839281_1_1_1_1,00.html

OECD (2003a), EAP Task Force, Data sets and performance indicators for Armenia, Azerbaijan, Georgia, Moldova, Kazakhstan, Kyrgyz Republic, Russian Federation, Tajikistan and Ukraine

OECD (2003b), Urban Water Reform in Eastern Europe, Caucasus and Central Asia, Progress since the Almaty Ministerial Conference

Tapio Saavalainen and Joy Ten Berge (2004), Energy Conditionality in Poor CIS Countries, IMF

Tapio Saavalainen and Joy Ten Berge (2006), Quasi Fiscal Deficits and Energy Conditionality in Selected CIS Countries, IMF Working Paper, WP/06/43

UNDP/GEF (2004), Assessment and Development of Municipal Water and Wastewater Tariffs and Effluent Charges in the Danube Basin, Danube Regional Project, Hungarian Environmental Centre

Vivien Foster and Tito Yepes (2005), Is Cost Recovery Feasible for Water and Electricity, The World Bank

World Bank (1999), Benchmarking Water and Sanitation Utilities: A Start-Up Kit, http://www.worldbank.org/html/fpd/water/topics/bench/bench_network_indicatordef.html

World Bank (2004), World Development Indicators Database

World Bank (2006), Measuring Financial Performance in Infrastructure, Report No.: 36058-ECA

World Bank (2006), ECADATA Indicators Database, http://ecadata-worldbank.org

WRc Group, http://www.wrcplc.co.uk 


\section{Annex 1. Calculating Hidden Costs in the Energy and Water Sectors}

\section{A. Model}

The model to calculate "hidden costs" in the infrastructure sector is described below. While there are more detailed and complex ways in which a model could be developed to reflect a loss in specific countries and sectors, this model has been formulated specifically to provide an insight into three key components of hidden costs: poor collections, tariffs set below cost-recovery levels and losses above normative levels. The intention in developing this model was to devise a simple-to-use methodology with which to monitor trends and to benchmark across sectors and countries without the need for intensive data collection efforts.

Let $\mathrm{H}$ be the "hidden costs" in the (electricity, gas or water) sector, defined as:

$\mathrm{H}=\mathrm{R}^{*}-\mathrm{R}$

Where,

$\mathrm{R}^{*}$ is the expected revenue in a system operating with tariffs that cover costs, where bills are paid and where losses are within normal levels expected for a system of that age and design.

$\mathrm{R}$ is the actual revenue.

If,

Qs, is the volume (electricity, gas or water) supplied to the transmission network.

$\mathrm{Qe}$, is the end-user consumption (of electricity, gas or water)

$\mathrm{Lm}$, are the losses in transmission and distribution (of electricity, gas or water). Lm includes normative losses, Ln where Ln are those losses that are expected in a system of that design and age as well as losses due to system inefficiencies outside norms and theft.

Then,

$\mathrm{Qs}=\mathrm{Qe}+\mathrm{Lm}$

And,

$\mathrm{R}^{*}=(\mathrm{Qs}-\mathrm{Ln}) \mathrm{Tc}$

Where Tc defined as the cost-recovery tariff, is the long run cost of operation and maintenance and includes a reasonable allowance for investment and normative losses.

And,

$\mathrm{R}=(\mathrm{Qs}-\mathrm{Lm}) \mathrm{Te} \mathrm{Rct}$

Where Te is defined as the weighted average end-user tariff, and Rct is the rate of collection of billed amounts.

Substituting for $\mathrm{R}^{*}$ and $\mathrm{R}$ in (1), using (3) and (4), then

$\mathrm{H}=(\mathrm{Q} s-\mathrm{Ln}) \mathrm{Tc}-(\mathrm{Q} s-\mathrm{Lm}) \mathrm{Te} \mathrm{Rct}$ 
$\mathrm{H}=(\mathrm{Qe}+\mathrm{Lm}-\mathrm{Ln}) \mathrm{Tc}-\mathrm{Qe}$ Te Rct

$\mathrm{H}=\mathrm{Qe}(\mathrm{Tc}-\mathrm{Te})+(\mathrm{Lm}-\mathrm{Ln}) \mathrm{Tc}-\mathrm{Qe} \mathrm{Te}(\mathrm{Rct}-1)$

$\mathrm{H}=\mathrm{Qe}(\mathrm{Tc}-\mathrm{Te})+\mathrm{Tc}(\mathrm{Lm}-\mathrm{Ln})+\mathrm{Qe} \mathrm{Te}(1-\mathrm{Rct})$

Total losses, Lm, can also be defined as lm Qs, or the rate of total losses multiplied by the volume (of electricity, gas or water) supplied to the system.

Normative losses, Ln, can in turn be defined as ln Qs, or the rate of normative losses multiplies by the volume (of electricity, gas or water) supplied to the system.

Therefore,

$\mathrm{Lm}-\mathrm{Ln}=(\operatorname{lm}-\ln ) \mathrm{Qs}$

Where Qs is defined in (2) as:

$\mathrm{Qs}=\mathrm{Qe}+\mathrm{Lm}$

Substituting for Lm, we have,

$\mathrm{Qs}=\mathrm{Qe}+\operatorname{lm} \mathrm{Qs}$

Qs $(1-\operatorname{lm})=\mathrm{Qe}$

Qs $=$ Qe $/(1-\operatorname{lm})$

Substituting for Qs in (6) using (7) gives:

$\mathrm{Lm}-\mathrm{Ln}=(\operatorname{lm}-\ln )$ Qe $/(1-\operatorname{lm})$

Hidden costs defined in (5) can therefore be expressed as:

$\mathrm{H}=\mathrm{Qe}(\mathrm{Tc}-\mathrm{Te})+\mathrm{Qe}$ Tc $(\mathrm{lm}-\mathrm{ln}) /(1-\operatorname{lm})+\mathrm{Qe}$ Te $(1-\mathrm{Rct})$

In performing the calculation if any of the three components of hidden costs defined above has a value of less than or equal to zero, it is set to zero.

Please note that tariffs set below cost-recovery levels as a matter of policy are considered an explicit subsidy and should be deducted from the overall calculation. In this case the correct measure of hidden costs would be

$\mathrm{H}=\mathrm{R}^{*}-\mathrm{R}-\mathrm{T}$

Where, $\mathrm{T}$ is the amount of capital or other transfer. No attempt has been made to estimate $\mathrm{T}$ in this paper and hidden costs may in some cases be overestimated. 


\section{B. Applying the Model: Key Assumptions}

\section{Adjustment of Financial Data to Constant US\$ (2001)}

In all cases currency tabulations for each year have been reported in constant US\$ 2001.

Most original data were obtained in year-specific local currency units. They were converted to US\$ using the average annual exchange rate (local currency to US\$) as reported in the World Bank World Development Indicators and subsequently calibrated to constant 2001 US\$ using the US\$ deflator series also in the World Development Indicators.

While using country-specific purchasing power parity indices would have generated similar constant 2001 US\$ currency values, this option was not chosen as data were not available for purchasing power parity for all the countries and for all the periods included in the paper.

\section{a) Water Sector}

\section{Specific Assumptions Made in Manipulating Data in the Water Sector}

In the water sector five specific assumptions have been made:

(i) The calculation of overall hidden costs is based on municipalities and urban settlements with centralized water services where the population is above 5,000. Rural settlements have been excluded from the calculation of subsidies as there is no systematic data collection and information gathering.

(ii) The normative level of water losses has been assumed to be 20 percent of produced water. This level is representative of developed water systems in England and Wales. ${ }^{5}$

(iii) To enable cross-country comparisons, indicators used in the calculation of overall hidden costs have been extrapolated from per capita average values that have been available for a representative sample of utilities. In extrapolating to a national average, per capita values have been multiplied by the urban population in the country. The result is considered to be representative for the following reasons: (a) for Russia, the data set covers more than 90 municipal water and sewerage utilities in four regions of the country ${ }^{6}$ serving over 7.6 million residents or 5.2 percent of total population; (b) in Ukraine the data set covers more than 60 municipal water and sewerage utilities in four oblasts $^{7}$ serving over 5.8 million residents or 10 percent of total population; and (c) for smaller countries the data set covers between 20 percent (for Kazakhstan) and 100 percent of the total urban population (Moldova and Armenia).

(iv) Average water tariffs have been calculated as the cost per cubic meter actually billed to a consumer (vs. declared tariffs) using data reported by the utilities to calculate the average tariff for an entire year. This approach avoids inconsistencies due to privileges for different consumer groups in different countries and cities.

\footnotetext{
${ }^{5}$ http://www.wrcplc.co.uk

${ }^{6}$ Samara oblast, Krasnodar krai, Leningrad oblast, Perm oblast, and several others from northwest Russia

${ }^{7}$ Kharkiv, Mykolayiv, Lviv, and Transcarpatia
} 
It is assumed that all assets have a life span of 25 years to ensure service standards are maintained. While this period is short it reflects the Soviet standard that is practiced in all countries of the paper.

\section{Calculation of Average Cost Recovery Price in the Water Sector}

Cost-recovery tariffs are defined as the cost of supplying water 24 hours a day, including the cost of operation, maintenance and necessary investments. Where an average cost-recovery price has not been available the following assumptions have been made in its calculation:

$\mathrm{ACRP}=[$ Current cost of operation $]+[24$ hours-a-day supply factor $]+[$ Investment component $]$

Where:

Current cost of operation, $C$ - The actual reported operation and maintenance cost collected from the OECD data set $^{8}$ or by using the IB-NET ${ }^{9}$ toolkit.

24 hours-a-day supply factor, $T$ - To reduce short-term costs, especially electricity costs, water utilities initiate intermittent water supply. Reducing operational hours results in some savings that reduce costs in the short run, but long-run costs increase dramatically due to hydraulic shocks that destroy the water infrastructure and other effects that reduce water quality. It has been assumed that savings incurred through interrupted water supplies are equal to one-quarter of the cost of maintaining supplies round the clock due to energy savings and reduced short-term maintenance. As a rule, intermittent water supply does reduce consumption.

Here,

$\mathrm{T}=0.25 \mathrm{C}(1-(\mathrm{t} / 24))$

Where,

$\mathrm{t}=$ number of hours of water supply

Investment Component, I - Assumed to be equivalent of 4 percent of the value of the assets per year on the basis that assets have a life span of 25 years to ensure service standards are maintained. The fixed asset value is reported in IB-NET.

$\mathrm{I}=0.04 \mathrm{~A} / \mathrm{P}$

Where,

A = fixed asset value in US\$

$\mathrm{P}=$ annual water production in $\mathrm{m}^{3}$

Therefore the Average Cost Recovery Price, ACRP equals

$\mathrm{ACRP}=\mathrm{C}+\mathrm{T}+\mathrm{I}$

$\mathrm{ACRP}=\mathrm{C}+0.25 \mathrm{C}(1-(\mathrm{t} / 24))+0.04 \mathrm{~A} / \mathrm{P}$

\footnotetext{
${ }^{8}$ www.oecd.org/document/49/0,2340,en_2649_34343_1839281_1_1_1_1,00.html

${ }^{9}$ http://www.ib-net.org/
} 
For example:

The water system of the country N provides water services 12 hours a day supplying 100,000 cubic meters of water a day to its consumers. The fixed asset value is $\$ 100$ million (approximately $\$ 100$ per capita). The reported cost of water services is $\$ 0.10$ per cubic meter.

ACRP is calculated as follows:

$\mathrm{C}=\mathrm{US} \$ 0.10$ per $\mathrm{m}^{3}$

$\mathrm{T}=0.25$ US\$ 0.10 per $\mathrm{m}^{3}(12 / 24)=\mathrm{US} \$ 0.013$ per $\mathrm{m}^{3}$

$\mathrm{I}=0.04 \mathrm{US} \$ 100,000,000 /\left(365 \times 100,000 \mathrm{~m}^{3}\right.$ per day $)=\mathrm{US} \$ 0.109$ per $\mathrm{m}^{3}$

And

ACRP $=$ US\$ 0.10 per $\mathrm{m}^{3}+$ US\$ 0.013 per $\mathrm{m}^{3}+$ US\$ 0.109 per $\mathrm{m}^{3}=\mathrm{US} \$ 0.22$ per $\mathrm{m}^{3}$

\section{Thresholds Used for the Average Cost-recovery Price in the Water Sector}

Where data are not readily available to calculate the Average Cost Recovery Price the following thresholds could be applied:

\begin{tabular}{|c|c|c|}
\hline & Developing countries & Industrialized countries \\
\hline$<\mathrm{US} \$ 0.20 / \mathrm{m}^{3}$ & $\begin{array}{l}\text { Tariff insufficient to cover basic operating } \\
\text { and maintenance costs }\end{array}$ & $\begin{array}{l}\text { Tariff insufficient to cover basic } \\
\text { operating and maintenance costs. }\end{array}$ \\
\hline US\$0.20-0.40/m $\mathrm{m}^{3}$ & $\begin{array}{l}\text { Tariff sufficient to cover operating and } \\
\text { some maintenance costs }\end{array}$ & $\begin{array}{l}\text { Tariff insufficient to cover basic } \\
\text { operating and maintenance costs. }\end{array}$ \\
\hline US\$0.40-1.00/m $\mathrm{m}^{3}$ & $\begin{array}{l}\text { Tariff sufficient to cover operating, } \\
\text { maintenance and most investment needs }\end{array}$ & $\begin{array}{l}\text { Tariff sufficient to cover operating and } \\
\text { maintenance costs }\end{array}$ \\
\hline$>\mathrm{US} \$ 1.00 / \mathrm{m}^{3}$ & $\begin{array}{l}\text { Tariff sufficient to cover operating, } \\
\text { maintenance and most investment needs } \\
\text { in the face of extreme supply shortages }\end{array}$ & $\begin{array}{l}\text { Tariff sufficient to cover full cost of } \\
\text { modern water systems in most high- } \\
\text { income cities }\end{array}$ \\
\hline
\end{tabular}

Source: Foster and Yepes, 2005

Normative Loss Rates

In the event that country specific data are unavailable for the normative loss rate "In", we would suggest the use of 0.2 in the water sector. 


\section{b) Energy Sector}

Thresholds used for the average cost-recovery price in the power sector

Where data are not readily available on the Average Cost Recovery Price in the power sector the following thresholds could be applied. Thresholds for the Average Cost Recovery Price in the gas sector have not been provided due to the wide variation in this parameter across countries in ECA.

\begin{tabular}{|c|c|c|}
\hline & Residential customers & Industrial customers \\
\hline$<$ US\$0.04/kWh & $\begin{array}{l}\text { Tariff insufficient to cover basic } \\
\text { operating and maintenance costs }\end{array}$ & $\begin{array}{l}\text { Tariff insufficient to cover basic } \\
\text { operating and maintenance costs. }\end{array}$ \\
\hline$>$ US\$0.05/kWh & & $\begin{array}{l}\text { Tariffs likely to be making a significant } \\
\text { contribution towards capital costs, in } \\
\text { most types of systems. }\end{array}$ \\
\hline$>$ US $\$ 0.08 / \mathrm{kWh}$ & $\begin{array}{l}\text { Tariffs likely to be making a significant } \\
\text { contribution towards capital costs, in } \\
\text { most types of systems. }\end{array}$ & \\
\hline
\end{tabular}

Source: Foster and Yepes, 2005

\section{Normative Loss Rates}

In the event that country specific data are unavailable for the normative loss rate "In", we would suggest the use of 0.1 (electricity) and 0.02 (gas). 


\section{Tables}

\section{Hidden Cost Calculations}

\section{Calculated Hidden Costs - The Power Sector}

\begin{tabular}{|c|c|c|c|c|c|c|c|c|c|c|c|c|c|c|c|c|c|c|c|c|}
\hline \multirow[t]{2}{*}{ Country } & \multicolumn{4}{|c|}{$\begin{array}{c}\text { Hidden Costs: } \\
\text { Unaccounted Losses [US\$ } \\
\text { million, } 2001 \text { constant] }\end{array}$} & \multicolumn{4}{|c|}{$\begin{array}{l}\text { Hidden Costs: Collection } \\
\text { Failures [US\$ million, } \\
2001 \text { constant] }\end{array}$} & \multicolumn{4}{|c|}{$\begin{array}{c}\text { Hidden Costs: Tariff Below } \\
\text { Cost Recovery [US\$ million, } \\
2001 \text { constant] }\end{array}$} & \multicolumn{4}{|c|}{$\begin{array}{l}\text { Hidden Costs: Total [US\$ } \\
\text { million, } 2001 \text { constant] }\end{array}$} & \multicolumn{4}{|c|}{$\begin{array}{c}\text { Hidden Costs: Total [\% } \\
\text { GDP] }\end{array}$} \\
\hline & 2000 & 2001 & 2002 & 2003 & 2000 & 2001 & 2002 & 2003 & 2000 & 2001 & 2002 & 2003 & 2000 & 2001 & 2002 & 2003 & 2000 & 2001 & 2002 & 2003 \\
\hline Albania & 168 & 131 & 143 & 135 & 36 & 19 & 16 & 14 & 193 & 165 & 133 & 98 & 397 & 315 & 292 & 247 & 10.49 & 7.41 & 6.14 & 4.16 \\
\hline Armenia & 9 & 9 & 11 & 18 & 16 & 25 & 12 & 5 & 3 & 12 & 0 & 5 & 28 & 46 & 23 & 27 & 1.42 & 2.19 & 0.98 & 1.00 \\
\hline Azerbaijan & 53 & 36 & 27 & 14 & 243 & 161 & 189 & 219 & 320 & 379 & 283 & 210 & 616 & 577 & 498 & 443 & 11.40 & 10.10 & 8.11 & 6.42 \\
\hline Belarus & 12 & 14 & 0 & 0 & 191 & 140 & 24 & 0 & 125 & 121 & 84 & 0 & 327 & 275 & 108 & 0 & 2.51 & 2.22 & 0.75 & 0.00 \\
\hline Bosnia & 53 & 45 & 41 & 0 & 0 & 20 & 0 & 4 & 199 & 190 & 172 & 92 & 251 & 255 & 212 & 96 & 5.40 & 5.08 & 3.85 & 1.42 \\
\hline Bulgaria & 157 & 120 & 131 & 133 & 88 & 95 & 102 & 74 & 975 & 889 & 845 & 521 & 1220 & 1104 & 1079 & 729 & 9.45 & 8.12 & 7.04 & 3.80 \\
\hline Croatia & 42 & 65 & 34 & 59 & 140 & 139 & 145 & 187 & 207 & 205 & 214 & 8 & 390 & 409 & 392 & 253 & 2.07 & 2.06 & 1.75 & 0.91 \\
\hline Georgia & 208 & 121 & 118 & 127 & 124 & 65 & 59 & 50 & 49 & 34 & 38 & 53 & 381 & 220 & 216 & 230 & 12.21 & 6.85 & 6.45 & 5.97 \\
\hline Kazakhstan & 218 & 213 & 163 & 140 & 141 & 148 & 159 & 175 & 262 & 274 & 267 & 69 & 621 & 635 & 589 & 384 & 3.31 & 2.87 & 2.43 & 1.33 \\
\hline Kyrgyz Republic & 122 & 283 & 211 & 83 & 20 & 9 & 12 & 29 & 119 & 93 & 77 & 57 & 261 & 385 & 301 & 169 & 18.64 & 25.23 & 19.02 & 9.16 \\
\hline Macedonia & 10 & 11 & 19 & 14 & 25 & 0 & 0 & 28 & 149 & 112 & 114 & 209 & 184 & 123 & 132 & 252 & 5.01 & 3.59 & 3.54 & 5.57 \\
\hline Moldova & 98 & 110 & 52 & 51 & 28 & 0 & 0 & 0 & 17 & 4 & 0 & 0 & 143 & 114 & 52 & 51 & 10.84 & 7.68 & 3.20 & 2.71 \\
\hline Poland & 168 & 259 & 169 & 173 & 92 & 105 & 0 & 0 & 163 & 2228 & 1850 & 1376 & 423 & 2592 & 2019 & 1549 & 0.25 & 1.40 & 1.07 & 0.76 \\
\hline Romania & 176 & 186 & 183 & 155 & 102 & 110 & 119 & 43 & 1162 & 1179 & 812 & 533 & 1440 & 1474 & 1114 & 731 & 3.80 & 3.67 & 2.47 & 1.33 \\
\hline Russia & 976 & 1062 & 916 & 525 & 680 & 947 & 790 & 0 & 12593 & 8909 & 8874 & 3708 & 14249 & 10918 & 10579 & 4233 & 5.36 & 3.56 & 3.11 & 1.01 \\
\hline Serbia and Montenegro & 254 & 248 & 113 & & 193 & 128 & 118 & 221 & 1529 & 1536 & 1137 & 1290 & 1977 & 1912 & 1368 & 1744 & 22.45 & 16.52 & 8.86 & 8.70 \\
\hline Tajikistan & 20 & 20 & 15 & 30 & 8 & 13 & 8 & 9 & 257 & 238 & 255 & 209 & 286 & 272 & 279 & 248 & 28.18 & 24.95 & 22.95 & 16.53 \\
\hline Turkey & 1467 & 1408 & 954 & 1035 & 637 & 663 & 758 & 449 & 1482 & 991 & 295 & 0 & 3586 & 3062 & 2008 & 1484 & 1.76 & 2.11 & 1.11 & 0.64 \\
\hline Ukraine & 377 & 466 & 449 & 368 & 391 & 285 & 218 & 147 & 2139 & 1838 & 1656 & 1413 & 2907 & 2588 & 2323 & 1928 & 9.08 & 6.81 & 5.56 & 4.03 \\
\hline Uzbekistan & 15 & 0 & 2 & 219 & 71 & 80 & 171 & 139 & 1119 & 1079 & 1077 & 802 & 1205 & 1159 & 1251 & 1159 & 8.55 & 10.16 & 13.11 & 12.05 \\
\hline Total & 4604 & 4805 & 3753 & 3280 & 3227 & 3153 & 2900 & 1793 & 23062 & 20477 & 18184 & 10652 & 30892 & 28436 & 24836 & 15958 & & & & \\
\hline Total CEE & 168 & 259 & 169 & 173 & 92 & 105 & 0 & 0 & 163 & 2228 & 1850 & 1376 & 423 & 2592 & 2019 & 1549 & & & & \\
\hline Total SEE & 2327 & 2213 & 1618 & 1531 & 1222 & 1174 & 1258 & 1021 & 5897 & 5268 & 3722 & 2751 & 9446 & 8655 & 6597 & 5535 & & & & \\
\hline Total FSU-LI & 525 & 579 & 437 & 543 & 511 & 354 & 452 & 450 & 1884 & 1839 & 1731 & 1336 & 2919 & 2771 & 2620 & 2329 & & & & \\
\hline Total FSU-MI & 1583 & 1755 & 1528 & 1033 & 1403 & 1520 & 1190 & 322 & 15119 & 11142 & 10881 & 5189 & 18104 & 14417 & 13600 & 6545 & & & & \\
\hline
\end{tabular}




\section{Calculated Hidden Costs - The Natural Gas Sector}

\begin{tabular}{|c|c|c|c|c|c|c|c|c|c|c|c|c|c|c|c|c|c|c|c|c|}
\hline \multirow[t]{2}{*}{ Country } & \multicolumn{4}{|c|}{$\begin{array}{l}\text { Hidden Costs: Unaccounted } \\
\text { Losses [US\$ million, } 2001 \\
\text { constant] }\end{array}$} & \multicolumn{4}{|c|}{$\begin{array}{l}\text { Hidden Costs: Collection } \\
\text { Failures [US\$ million, } 2001 \\
\text { constant] }\end{array}$} & \multicolumn{4}{|c|}{$\begin{array}{c}\text { Hidden Costs: Tariff Below } \\
\text { Cost Recovery [US\$ million, } \\
2001 \text { constant] }\end{array}$} & \multicolumn{4}{|c|}{$\begin{array}{l}\text { Hidden Costs: Total [US\$ } \\
\text { million, } 2001 \text { constant] }\end{array}$} & \multicolumn{4}{|c|}{ Hidden Costs: Total [\% GDP] } \\
\hline & 2000 & 2001 & 2002 & 2003 & 2000 & 2001 & 2002 & 2003 & 2000 & 2001 & 2002 & 2003 & 2000 & 2001 & 2002 & 2003 & 2000 & 2001 & 2002 & 2003 \\
\hline Armenia & & & 0 & 13 & 7 & 4 & 3 & 0 & 0 & 0 & 0 & 0 & 7 & 4 & 4 & 13 & 0.38 & 0.19 & 0.15 & 0.48 \\
\hline Azerbaijan & 4 & 1 & 2 & 3 & 64 & 51 & 38 & 43 & 8 & 16 & 27 & 16 & 76 & 68 & 67 & 62 & 1.40 & 1.19 & 1.09 & 0.89 \\
\hline Belarus & 2 & 1 & 2 & 1 & 72 & 72 & 0 & 0 & 175 & 174 & 180 & 77 & 250 & 247 & 182 & 78 & 1.92 & 1.99 & 1.29 & 0.46 \\
\hline Bulgaria & 1 & 8 & 3 & 7 & 23 & 22 & 19 & 16 & 153 & 113 & 85 & 173 & 177 & 144 & 107 & 195 & 1.37 & 1.06 & 0.70 & 1.01 \\
\hline Croatia & 3 & 6 & 2 & 2 & 0 & 22 & 24 & & & 3 & 0 & 0 & 3 & 31 & 26 & 2 & 0.02 & 0.16 & 0.11 & 0.01 \\
\hline Georgia & & 19 & 1 & & 25 & 43 & 41 & & 5 & 0 & 0 & 0 & 30 & 62 & 42 & 0 & 0.95 & 1.95 & 1.24 & 0.00 \\
\hline Kazakhstan & & & & & & & & & & & & 191 & & & & 191 & & & & 0.66 \\
\hline $\begin{array}{l}\text { Kyrgyz } \\
\text { Republic }\end{array}$ & & & & & 2 & 1 & 0 & 0 & 3 & 2 & 6 & 0 & 6 & 3 & 6 & 0 & 0.41 & 0.20 & 0.40 & 0.00 \\
\hline Moldova & 1 & 1 & 0 & & 9 & 9 & 9 & 15 & 0 & 0 & 3 & 2 & 10 & 9 & 12 & 17 & 0.77 & 0.63 & 0.76 & 0.91 \\
\hline Poland & 55 & 42 & 43 & & 164 & 214 & 207 & & 535 & 53 & 22 & 39 & 755 & 309 & 272 & 39 & 0.44 & 0.17 & 0.14 & 0.02 \\
\hline Romania & 2 & 8 & & & 143 & 135 & 7 & 34 & 236 & 176 & 200 & 104 & 381 & 319 & 208 & 138 & 1.00 & 0.79 & 0.46 & 0.24 \\
\hline Russia & & & & & 200 & 89 & 127 & & 2865 & 2683 & 2348 & 1644 & 3065 & 2772 & 2475 & 1644 & 1.15 & 0.90 & 0.72 & 0.39 \\
\hline Tajikistan & & & 0 & 3 & 8 & 8 & 11 & 0 & 13 & 12 & 2 & 2 & 21 & 20 & 13 & 5 & 2.04 & 1.92 & 1.14 & 0.39 \\
\hline Turkey & & & & 623 & 192 & 224 & 260 & & 0 & 0 & 0 & 0 & 192 & 224 & 260 & 623 & 0.09 & 0.15 & 0.14 & 0.27 \\
\hline Ukraine & 31 & 55 & & & 388 & 312 & 441 & 383 & 771 & 1566 & 0 & 113 & 1190 & 1934 & 441 & 496 & 3.72 & 5.09 & 1.05 & 1.03 \\
\hline Uzbekistan & 9 & 9 & & & 116 & 96 & 145 & & 291 & 277 & 423 & 125 & 416 & 383 & 568 & 125 & 2.95 & 3.36 & 5.93 & 1.29 \\
\hline Total & 109 & 150 & 54 & 651 & 1415 & 1303 & 1332 & 491 & 5055 & 5077 & 3298 & 2485 & 6578 & 6529 & 4684 & 3628 & & & & \\
\hline Total CEE & 55 & 42 & 43 & 0 & 164 & 214 & 207 & 0 & 535 & 53 & 22 & 39 & 755 & 309 & 272 & 39 & & & & \\
\hline Total SEE & 7 & 22 & 5 & 632 & 358 & 404 & 310 & 50 & 388 & 292 & 285 & 277 & 753 & 718 & 601 & 958 & & & & \\
\hline $\begin{array}{l}\text { Total FSU- } \\
\text { LI }\end{array}$ & 14 & 30 & 4 & 19 & 232 & 212 & 247 & 58 & 319 & 308 & 462 & 145 & 565 & 549 & 712 & 222 & & & & \\
\hline $\begin{array}{l}\text { Total FSU- } \\
\text { MI }\end{array}$ & 33 & 56 & 2 & 1 & 660 & 473 & 568 & 383 & 3812 & 4423 & 2529 & 2024 & 4505 & 4953 & 3098 & 2409 & & & & \\
\hline
\end{tabular}




\section{Calculated Hidden Costs - The Water Sector}

\begin{tabular}{|c|c|c|c|c|c|c|c|c|c|c|c|c|c|c|c|c|c|c|c|c|}
\hline \multirow[t]{2}{*}{ Country } & \multicolumn{4}{|c|}{$\begin{array}{c}\text { Hidden Costs: Unaccounted } \\
\text { Losses [US\$ million, } 2001 \\
\text { constant] }\end{array}$} & \multicolumn{4}{|c|}{$\begin{array}{l}\text { Hidden Costs: Collection } \\
\text { Failures [US\$ million, } 2001 \\
\text { constant] }\end{array}$} & \multicolumn{4}{|c|}{$\begin{array}{c}\text { Hidden Costs: Tariff Below } \\
\text { Cost Recovery [US\$ million, } \\
2001 \text { constant] }\end{array}$} & \multicolumn{4}{|c|}{$\begin{array}{l}\text { Hidden Costs: Total [US\$ } \\
\text { million, } 2001 \text { constant] }\end{array}$} & \multicolumn{4}{|c|}{ Hidden Costs: Total [\% GDP] } \\
\hline & 2000 & 2001 & 2002 & 2003 & 2000 & 2001 & 2002 & 2003 & 2000 & 2001 & 2002 & 2003 & 2000 & 2001 & 2002 & 2003 & 2000 & 2001 & 2002 & 2003 \\
\hline Armenia & & 45 & 83 & 90 & & 2 & 3 & 2 & & 10 & 25 & 34 & & 57 & 111 & 126 & & 2.7 & 4.7 & 4.6 \\
\hline Azerbaijan & & & & & 8 & 1 & & & 14 & 12 & 19 & & 21 & 13 & 19 & & 0.4 & 0.2 & 0.3 & \\
\hline Belarus & 9 & 9 & & & 14 & 14 & & & 36 & 37 & & & 59 & 60 & & & 0.5 & 0.5 & & \\
\hline Bulgaria & 169 & 125 & 131 & 128 & 12 & 15 & 23 & 23 & 96 & 74 & 54 & 44 & 277 & 214 & 208 & 195 & 2.2 & 1.6 & 1.4 & 1.0 \\
\hline Czech Republic & 49 & 40 & & & 30 & 31 & & & 8 & & & & 87 & 71 & & & 0.2 & 0.1 & & \\
\hline Estonia & & & 76 & & & & 5 & & & & 22 & & & & 103 & & & & 1.5 & \\
\hline Georgia & 22 & 26 & 26 & 26 & & 5 & & & 36 & 40 & 37 & 34 & 58 & 72 & 62 & 60 & 1.9 & 2.2 & 1.9 & 1.5 \\
\hline Kazakhstan & 32 & 34 & 45 & & & & & & 23 & 23 & 32 & & 55 & 56 & 77 & & 0.3 & 0.3 & 0.3 & \\
\hline Kyrgyz Republic & 5 & 4 & 5 & & & & & & & & & & 5 & 4 & 5 & & 0.4 & 0.3 & 0.3 & \\
\hline Latvia & & & & & & & 30 & & & & 59 & & & & 89 & & & & 1.0 & \\
\hline Moldova & 18 & 28 & 28 & 28 & 5 & 1 & 3 & 2 & 25 & 24 & 23 & 17 & 48 & 53 & 53 & 47 & 3.6 & 3.6 & 3.3 & 2.5 \\
\hline Poland & 247 & 247 & 288 & 307 & 11 & 12 & 13 & 14 & 122 & 144 & 167 & 165 & 394 & 416 & 468 & 474 & 0.2 & 0.2 & 0.3 & 0.2 \\
\hline Romania & & & & 208 & & & & 24 & & & & 365 & & & & 597 & & & & 1.1 \\
\hline Russia & 63 & 88 & 208 & 130 & 613 & 310 & & & 770 & 812 & 296 & 660 & 1446 & 1209 & 477 & 791 & 0.5 & 0.4 & 0.1 & 0.2 \\
\hline Tajikistan & & & & & 2 & & & & 2 & 1 & 1 & & 3 & 1 & 1 & & 0.3 & 0.1 & 0.1 & \\
\hline Ukraine & 12 & 28 & 49 & 64 & 19 & 58 & 60 & 52 & 8 & 30 & 51 & 64 & 99 & 45 & 159 & 179 & 0.1 & 0.3 & 0.4 & 0.4 \\
\hline Total & 626 & 574 & 939 & 981 & 714 & 450 & 137 & 118 & 1140 & 1206 & 785 & 1383 & 2552 & 2271 & 1832 & 2469 & & & & \\
\hline Total CEE & 296 & 287 & 364 & 307 & 41 & 43 & 48 & 14 & 130 & 144 & 249 & 165 & 481 & 487 & 660 & 474 & & & & \\
\hline Total SEE & 169 & 125 & 131 & 336 & 12 & 15 & 23 & 47 & 96 & 74 & 54 & 409 & 277 & 214 & 208 & 792 & & & & \\
\hline Total FSU-LI & 45 & 103 & 142 & 144 & 15 & 10 & 6 & 4 & 77 & 87 & 104 & 85 & 135 & 200 & 251 & 233 & & & & \\
\hline Total FSU-MI & 116 & 159 & 302 & 194 & 646 & 382 & 60 & 52 & 837 & 901 & 378 & 724 & 1659 & 1370 & 713 & 970 & & & & \\
\hline
\end{tabular}




\section{Annex 2. Data Sources, Availability, and Definitions}

The following sections outline data availability, sources, and definitions of variable by sector. The full data set supporting this paper can be accessed at http://ecadata-worldbank.org.

\section{The Energy Sector}

In the energy (power and natural gas) sector data have proved to be generally available for twenty-two countries in the ECA Region through external data sets particularly where these data relate to energy production, consumption, import, export, and loss statistics and to a slightly lesser degree tariffs. Loss statistics have been generally available in the power sector but have been patchy at best for the natural gas sector.

Key data sets accessed include ENERDATA and ERRANET; however there have been no externally available data sets for cross-country data on normative losses, collection rates, and cost-recovery prices. For the purpose of this exercise these data have been sourced through World Bank Group sector specialists that are working in these countries. While efforts have been made to verify and assure the quality of data provided and to check for consistency and outliers in data sets, there has been no fieldbased data collection effort or audit in the Region.

A summary of data sources follows:

- Values for domestic energy production, imports, exports, and change in stocks - which together account for the total domestic supply-have been obtained from ENERDATA (http://www.enerdata.fr/) through subscription.

- Energy tariff rates have been obtained from ERRANET through subscription. (http://www.erranet.org/Products/TariffDatabase/TariffIndex)

- The Bank's World Development Indicators Database (2004) is the source for GDP, Exchange Rate, and Price Deflators.

- Sector specialists — based at the World Bank office in Washington, DC, or in World Bank country offices, have provided supplementary data on the energy sector, or have suggested corrections in the values reported in ENERDATA or ERRANET. Such expert data, where available, have been used to substitute primary data.

\section{Data Availability}

For the analysis, countries included in the data set have been classified into groups based on a combination of geographic and economic criteria. The data set covers the four-year period 2000-03. 


\begin{tabular}{lll}
\hline Name & Acronym $^{\mathbf{1 0}}$ & Countries Included \\
\hline Central and Eastern Europe & CEE (2) & Hungary, Poland \\
\hline South East Europe & SEE (8) & $\begin{array}{l}\text { Albania, Bosnia, Bulgaria, Croatia, Macedonia, Romania, Serbia } \\
\text { and Montenegro, Turkey }\end{array}$ \\
\hline $\begin{array}{lll}\text { Former Soviet Union - Low } \\
\text { Income Countries }\end{array}$ & FSU-LI (8) & $\begin{array}{l}\text { Armenia, Azerbaijan, Georgia, Moldova, Kyrgyz Republic, } \\
\text { Tajikistan, Turkmenistan, Uzbekistan }\end{array}$ \\
\hline $\begin{array}{l}\text { Former Soviet Union - } \\
\text { Middle Income Countries }\end{array}$ & FSU-MI (4) & Belarus, Kazakhstan, Russia, Ukraine \\
\hline
\end{tabular}

\section{Description of Variables}

\begin{tabular}{|c|c|c|}
\hline Indicator & Unit & Definition \\
\hline $\begin{array}{l}\text { Average Cost } \\
\text { Recovery Price } \\
\text { (ACRP) }\end{array}$ & $\begin{array}{l}\text { US\$/ kWh (power) } \\
\text { US\$ per } 1000 \text { m3 or US\$ } \\
\text { per mcm (gas) }\end{array}$ & $\begin{array}{l}\text { Average cost-recovery price at the end-user level defined as long } \\
\text { run operations and maintenance costs plus allowance for } \\
\text { reasonable investment and normative losses. }\end{array}$ \\
\hline Collection Rate & $\begin{array}{l}\text { rate (as a proportion of } \\
\text { billed consumption) }\end{array}$ & $\begin{array}{l}\text { This is the proportion of the billed charges to consumers of the } \\
\text { respective energy that is actually collected in some form by the } \\
\text { utility/service provider. }\end{array}$ \\
\hline $\begin{array}{l}\text { End-User } \\
\text { Consumption }\end{array}$ & $\begin{array}{l}\text { kWh metered or otherwise } \\
\text { observed (power) } \\
\text { thousand m3 (mcm) } \\
\text { metered or otherwise } \\
\text { observed (gas) }\end{array}$ & $\begin{array}{l}\text { End-user consumption measures the needs of the final consumers } \\
\text { of the country. They are broken down into several categories: } \\
\text { industry, transport, residential, tertiary, agriculture and non- } \\
\text { energetic uses. This measure is the actual final consumption that is } \\
\text { marketed by the utilities, which is the difference between domestic } \\
\text { consumption and the consumption that results from the } \\
\text { transformation process, and the losses involved, for each country. } \\
\text { In ENERDATA tables, the values correspond to Total Final } \\
\text { Consumption. }\end{array}$ \\
\hline Normative Loss & $\begin{array}{l}\text { Rate, as a proportion of } \\
\text { power injected into } \\
\text { transmission } \\
\text { Rate, as a proportion of } \\
\text { gas produced for transport }\end{array}$ & $\begin{array}{l}\text { Normative losses are that component of total losses that accrue } \\
\text { due to system design and technology constraints; they are } \\
\text { inevitable and predictable. }\end{array}$ \\
\hline Total Loss & $\begin{array}{l}\text { Rate, as a proportion of } \\
\text { power injected into } \\
\text { transmission }\end{array}$ & $\begin{array}{l}\text { Rate of actual losses in transmission and distribution due to } \\
\text { technical issues and due to theft. ENERDATA is the primary } \\
\text { source for transmission and distribution losses, supplemented with } \\
\text { data from sector specialists where available. }\end{array}$ \\
\hline WAET & $\begin{array}{l}\text { USc/ kWh (power) } \\
\text { US\$/ } 1000 \mathrm{~m} 3 \text { or U\$ per } \\
\text { mcm (gas) }\end{array}$ & Weighted average end-user tariff. \\
\hline
\end{tabular}

\footnotetext{
${ }^{10}$ Number of counties shown in parentheses.
} 


\section{The Water Sector}

The water sector review draws primarily upon data from utility surveys carried out by the Organization for Economic Cooperation and Development (OECD) and East Asia Pacific Region (EAP) Task Force in 2001-03 and now available through IB-NET. The original OECD country data sets are based on samples from utilities across the country, and the approach that has been taken by the OECD has been to multiply per capita averages for the sample by the urban population to arrive at a national average.

IB-NET otherwise known as the International Benchmarking Network for Water and Sanitation Utilities collects standard utilities performance indicators. The objective of IB-NET is to support access to comparative information that will help promote best practice among water supply and sanitation providers worldwide and eventually will provide consumers with access to high quality, and affordable water supply and sanitation services.

IB-NET sets forth a common set of data definitions and a minimum set of core indicators which, with some modifications and supplements from data sources from secondary sources, have been used for estimating hidden costs and presenting a picture of technical and financial performance of the water sector. The IBNET website is http://www.ib-net.org/.

A summary of data sources follows:

- Armenia, Azerbaijan, Georgia, Kazakhstan, Kyrgyz Republic, Moldova, Russian Federation, Tajikistan (all 2001-2003) and Ukraine (2000-2001) use data collected by the OECD EAP Task Force (now available through: www.ib-net.org).

- Albanian data have been sourced from the National Water Association report, 2003.

- Data for Danube basin countries (Czech Republic, Hungary, Serbia and Montenegro, Romania, Slovak Republic, Croatia, Bulgaria, and Bosnia Herzegovina) have been sourced from UNDP/GEF (2004).

- Data for European Union accession countries have been sourced though ISPA reports (20002004).

- Data for Belarus have been sourced through the State of Environment report, Ministry of Environment, 2003.

- Data for Poland (2000-03) and Ukraine (2002-03) have been sourced through national experts on the basis of reports from national municipal water authorities.

- The Bank’s World Development Indicators Database (2004) is the source for GDP, Exchange Rate, and Price Deflators.

- Data from various environmental and water sector reports have been used to supplement primary data.

\section{Data Availability}

Data have been collated for sixteen countries ${ }^{11}$ that have been classified into groups based on a combination of geographic and economic criteria. The data set covers the four-year period 2000-03, but in

\footnotetext{
${ }^{11}$ For the analysis of hidden costs, 11 of the 16 countries have data available for 3-4 years.
} 
some cases the analysis is presented for the year 2002 because data are available for most countries and because there have not been significant changes in the trend across this four-year period.

\begin{tabular}{|c|c|c|}
\hline Name & Acronym $^{12}$ & Countries Included \\
\hline Central and Eastern Europe & CEE (4) & Czech Republic, Estonia, Latvia, Poland \\
\hline South East Europe & SEE (2) & Bulgaria, Romania \\
\hline $\begin{array}{l}\text { Former Soviet Union } \\
\text { Low Income Countries }\end{array}$ & FSU-LI (6) & $\begin{array}{l}\text { Armenia, Azerbaijan, Georgia, Moldova, Kyrgyz Republic, } \\
\text { Tajikistan }\end{array}$ \\
\hline $\begin{array}{l}\text { Former Soviet Union - } \\
\text { Middle Income Countries }\end{array}$ & FSU-MI (4) & Belarus, Kazakhstan, Russia, Ukraine \\
\hline
\end{tabular}

Description of Variables

\begin{tabular}{|c|c|c|}
\hline Indicator & Unit & Definition \\
\hline $\begin{array}{l}\text { Average Cost } \\
\text { Recovery Price } \\
\text { (ACRP) }\end{array}$ & $\mathrm{US} \$ / \mathrm{m}^{3}$ & $\begin{array}{l}\text { The cost of } 24 \text { hours of water supply, where costs include operation, } \\
\text { maintenance and necessary investments (equivalent to } 4.0 \text { percent of the } \\
\text { value of utility assets per year) }{ }^{13} \text {. }\end{array}$ \\
\hline Collection Rate & $\begin{array}{l}\text { rate (as a } \\
\text { proportion of } \\
\text { billed } \\
\text { consumption) }\end{array}$ & $\begin{array}{l}\text { This is the proportion of the billed charges to consumers of the respective } \\
\text { energy that is actually collected in some form by the utility/service provider. }\end{array}$ \\
\hline $\begin{array}{l}\text { Continuity of } \\
\text { Service }\end{array}$ & hr/day & Average hours of water service per day. \\
\hline Cost of Assets & US\$/capita & Total annual net fixed assets per (water) capita served \\
\hline $\begin{array}{l}\text { End User } \\
\text { Consumption }\end{array}$ & $\mathrm{m}^{3}$ & This measure is the actual final consumption that is marketed by the utilities \\
\hline Investment & US\$ & Total annual investments per (water). \\
\hline Labor Costs & US\$ & Total annual utility reported labor costs (including benefits). \\
\hline Net Fixed Assets & US\$ & Total annual net fixed assets per (water). \\
\hline Pipe Breaks & breaks/km/yr & $\begin{array}{l}\text { Total number of pipe breaks per year expressed per } \mathrm{km} \text { of the water } \\
\text { distribution network. }\end{array}$ \\
\hline $\begin{array}{l}\text { Population } \\
\text { Served }\end{array}$ & - & $\begin{array}{l}\text { Population within the administrative area of the water utility and connected } \\
\text { to the services. }\end{array}$ \\
\hline Total Revenues & $\%$ & $\begin{array}{l}\text { Total annual operating revenues per population served expressed as a } \\
\text { percentage of the GDP per capita. }\end{array}$ \\
\hline $\begin{array}{l}\text { Unaccounted- } \\
\text { for-Water }\end{array}$ & $\mathrm{m} 3 / \mathrm{km} / \mathrm{d}$ & $\begin{array}{l}\text { Difference between water supplied and water sold as volume of water "lost" } \\
\text { per km of water distribution network per day. }\end{array}$ \\
\hline WAET & $\mathrm{US} \$ / \mathrm{m}^{3}$ & $\begin{array}{l}\text { Weighted Average End-user Tariff, calculated by dividing the total annual } \\
\text { operating revenues by the annual volume of water sold. }\end{array}$ \\
\hline Water Coverage & $\%$ & $\begin{array}{l}\text { Percentage of the population with easy access to water services (either with } \\
\text { direct service connection or within } 200 \mathrm{~m} \text { of a stand-post) divided by the } \\
\text { total population under the utility's nominal responsibility. }\end{array}$ \\
\hline Working Ratio & - & $\begin{array}{l}\text { Total annual operational costs divided by the total annual operating } \\
\text { revenues. }\end{array}$ \\
\hline
\end{tabular}

Source: World Bank, Benchmarking Water \& Sanitation Utilities: A Start-Up Kit, 1999:

http://www.worldbank.org/html/fpd/water/topics/bench/bench_network_indicatordef.html

Average Cost Recovery Price - internal definition.

\footnotetext{
12 Number of counties shown in parentheses.

${ }^{13}$ Adjusted to constant 2001 US dollars
} 